\title{
Management of Oral Hygiene through Ayurveda: A Case Study
}

\author{
Shravani Gawande ${ }^{1}$, Gulab Chand Pamnani ${ }^{2}$, Sharad Bhatnagar ${ }^{3}$ \\ ${ }^{1}$ P.G Scholar, Department of Shalakya Tantra, National Institute of Ayurveda, Jaipur, India \\ ${ }^{2}$ Associate Professor, Department of Shalakya Tantra, National Institute of Ayurveda, Jaipur, India \\ ${ }^{3}$ Consultant Dentist, National Institute of Ayurveda, Jaipur, India
}

Corresponding Author: Shravani Gawande

\begin{abstract}
Ayurveda is the ancient Indian system of health care and longevity. It involves a holistic view of man, his health and illness. Even though dentistry was not a specialised branch of Ayurveda, it is included in Shalakya Tantra. Oral diseases continue to be a major health problem worldwide. Oral health also reflects body health. For prevention and treatment of oral diseases modern medicine has limited success.

Ayurveda is good alternate for that and may lead to novel preventive or therapeutic strategies for oral health. This 500 years old system of medicine not only recommends treatment with specific herbs and minerals to cure oral diseases but also recommends some daily use therapeutic procedures for the prevention of and maintenance of oral health.

Recently there is grown interest in use of ayurvedic drugs for oral health and proper hygiene. Ayurveda herbs and natural products have been used for their pharmacological applications, wound healing, anti-inflammatory, antimicrobial, antioxidant properties have been proven to be safe and effective for oral disease and hygiene including various therapeutic ayurvedic procedures.
\end{abstract}

Keywords: Oral health, Oral diseases, Ayurvedic herbs

\section{INTRODUCTION}

Ayurveda, the fountain head of Indian Medicine was conceived as a science and preached in the country since thousand years, long before other countries could dream of systematizing the concept of remedies for human diseases.

Shalakya Tantra is one among the 8 specialities of Astanga Ayurveda, which considers the disease above clavicle; it includes Eye, Ear, Nose, Throat and Orodental diseases and their management along with their structural and functional details.

Oral Hygiene is not described as a separate chapter in Ayurveda but it comes under Ayurvedic Literature. Acharya Charak mentioned it under the topic "Swasthyavrata" which means personal hygiene in "Mattrashittiyaadhyaye".
Acharya Sushruta has mentioned it under the topic "Anagatabhadapratished". Acharya Vagbhata has mentioned it under the topic "Dincharya".

All the authors have given emphasis on personal hygiene which should be followed by each individual strictly.

Oral health is an integral to general wellbeing and relates to quality of life. The link between oral diseases and the activities of microbial species that form part of micro biodata of the oral cavity is well established. There is evidence that oral biofilm associated diseases may affect systemic health by spreading infections to adjacent tissues and space. Hence prevention and treatment of oral disease is not only important for maintenance of good oral health but also for general health. 
For prevention and treatment of oral diseases modern medicine has limitation. Oral health care professionals need to put home oral hygiene at priority of their advice on preventive practice.

\section{CASE REPORT}

A 52 year old male patient came to dental OPD of National Institute of Ayurveda, Jaipur on 15 July 2021 with complain of swelling and bleeding from gums and discolouration of teeth since 6 months and constant foul smell from mouth.

On detailed history taking, the patient revealed that he did not have undergone any dental treatment before and only had constant discolouration of teeth.

There was no familial history. No history of Hypertension and Diabetic Mellitus.

The patient was medically fit and well and had no history of smoking or drinking. He had no history of constipation. He had normal diet and there was no history of dry mouth. There was assessment of Oral Hygiene Index scoring.

Clinical Examination shows presence of debris and calculus deposits.

\section{Oral Hygiene Index - Simplified (OHI-S)} by Green and Vermillion

This index is required to evaluate the oral hygiene status of individual. This index is simplified to consider only six teeth which will represent all the teeth in the oral cavity. They are 16, 11, 26, 36, 31, 46. Further only one surface of each tooth examined will be taken into consideration i.e facial surface of $16,11,26,31$ and lingual surfaces of 36 and 46.

Oral hygiene index has two components: Debris index Simplified (DI-S) and Calculus Index Simplified (CI-S).

Debris Index - Simplified (DI-S)

Criteria for scoring debris index:

\begin{tabular}{|l|l|}
\hline 0 & No debris or no stains present \\
\hline 1 & Debris present up to gingival $1 / 3^{\text {rd }}$ or crown \\
\hline 2 & Debris present more than $1 / 3^{\text {rd }}$ but less than $2 / 3^{\text {rd }}$ of crown \\
\hline 3 & Debris present more than $2 / 3^{\text {rd }}$ of crown \\
\hline
\end{tabular}

DI- $\mathrm{S}=$ Total no. of scores $/ 6$
Calculus Index - Simplified (CI-S)

Criteria for scoring calculus index:

\begin{tabular}{|l|l|}
\hline 0 & No Calculus present \\
\hline 1 & $\begin{array}{l}\text { Only Supragingival calculus covering less than } 1 / 3^{\text {rd }} \\
\text { clinical crown }\end{array}$ \\
\hline 2 & $\begin{array}{l}\text { Supragingival Calculus covering more than } 1 / 3^{\text {rd }} \text { and or flecks } \\
\text { or subgingival calculus }\end{array}$ \\
\hline 3 & $\begin{array}{l}\text { Supragingival calculus covering more than } 2 / 3^{\text {rd }} \text { of clinical } \\
\text { crown or/ and continuous band of subgingival calculus. }\end{array}$ \\
CI-S = Total no of scores/ 6 \\
OHI-S = DI-S + CI-S
\end{tabular}

Clinical levels of oral hygiene can be assessed by OHI-S as follows

\begin{tabular}{|l|l|}
\hline Good & 0 to 1.2 \\
\hline Fair & 1.3 to 3.0 \\
\hline Poor & 3.1 to 6.0 \\
\hline
\end{tabular}

\section{ON EXAMINATION:}

\section{A) EXTRA ORAL}

Eyes - NAD

Facial symmetry - Apparently Symmetrical Lips - Competent

Lymph nodes - Not Palpable

\section{B) INTRA ORAL}

Halitosis - Present

Labial mucosa - NAD

Buccal mucosa - NAD

Floor of the mouth - NAD

Tongue - NORMAL

Vestibule - NAD

Tonsillar pillars and Pharynx - NAD

C) HARD TISSUE EXAMINATION:

Missing teeth - All teeth are present

Stains/ Discolouration - Present

Calculus - Moderate

Caries - Absent

Tenderness on percussion - NAD

Oral Hygiene Index - Simplified (by Green and Vermillion): Before treatment Debris Index:

\begin{tabular}{|c|c|c|c|}
\hline 16 & & & 26 \\
\hline 01 & 02 & 03 & \\
\hline 02 & 01 & 01 & \\
\hline
\end{tabular}

$\mathrm{DI}=10 / 6=1.66$

\section{Calculus Index:}

\begin{tabular}{|l|ll|ll|}
16 & 02 & & 03 & 26 \\
\hline 01 & 01 & & 01 & \\
\hline 03 & 31 & & 36 \\
\hline 46 &
\end{tabular}


$\mathrm{OHI}-\mathrm{S}=\mathrm{DI}+\mathrm{CI}=1.66+1.83=3.49$ (Poor Oral Hygiene)

\section{Treatment Administered:}

1) Education and motivation for maintaining Oral hygiene.
2) Dantarogashani churna to be used as paste for brushing for 15 days.

3) Gandusha with Triphala Kwath for 15 days.

\section{Drugs:}

1) DANTAROGASHANI CHURNA 5 -

\begin{tabular}{|l|l|l|l|l|l|}
\hline DRUG NAME & RASA & GUNA & VEERYA & VIPAKA & PARTS USED \\
\hline Chameli Patra & Tikta, Kashya & Laghu, Snigdha & Ushna & Katu & 1 part \\
\hline Punarnavamool & Madhura, Tikta, Kashya & Laghu, ruksha & ushna & madhura & 1 part \\
\hline Tila & Madhura & Guru, Snigdha & Ushna & Madhura & 1 part \\
\hline Piper & Katu & Laghu, Snigdha & Anushitushna & Madhura & 1 part \\
\hline Sahchar & Tikta, Madhura & Laghu & Ushna & Katu & 1 part \\
\hline Nagarmotha & Katu, Tikta, Kashya & Laghu, Ruksha & Shita & Katu & 1 part \\
\hline Vacha & Katu,Tikta & Laghu, Tikshna & Ushna & Katu & 1 part \\
\hline Shunthi & Katu & Ruksha, Tikshna & Ushna & Madhura & 1 part \\
\hline Yavani & Katu, Tikta & Laghu, Ruksha, Tikshna & Ushna & Katu & 1 part \\
\hline Haritaki & Panchras (kashyapradhan) & Laghu, Ruksha & Ushna & Madhura & 1 part \\
\hline
\end{tabular}

\section{2) TRIPHALA CHURNA KWATH ${ }^{6}$ :}

\begin{tabular}{|l|l|l|l|l|l|}
\hline DRUG NAME & RASA & GUNA & VEERYA & VIPAKA & PARTS USED \\
\hline Haritaki & Panchras (kashyapradhan) & Laghu, Ruksha & Ushna & Madhura & 1 part \\
\hline vibhitaki & Kashaya & Laghu, Ruksha & Ushna & Madhura & 2 Part \\
\hline Amalaki & Panchras (Alavana) & Guru & Sheeta & Madhura & 3 Part \\
\hline
\end{tabular}

\section{DRUG ADMINISTRATION:}

\section{1) DANTAROGASHANI CHURNA}

DOSE- 1-3 gm (Twice a day)

DURATION-15 days

MODE- Local application (Pratisaran)

ANUPANA- Ghrita

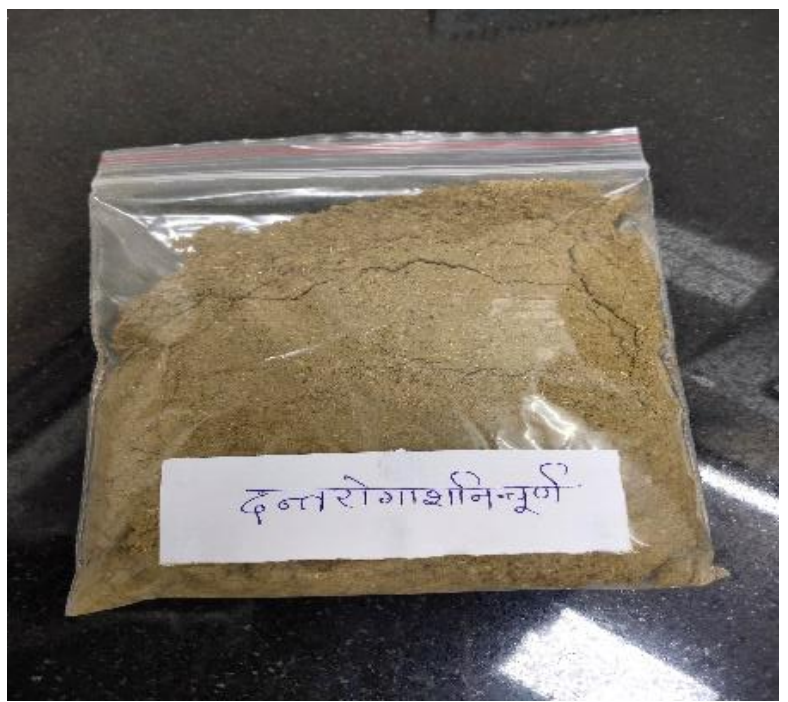

\section{2) TRIPHALA KWATH:}

DOSE- $10 \mathrm{ml}$ (Twice a day)

DURATION-15 days

MODE- Local (Gandusha)

ANUPANA-Water

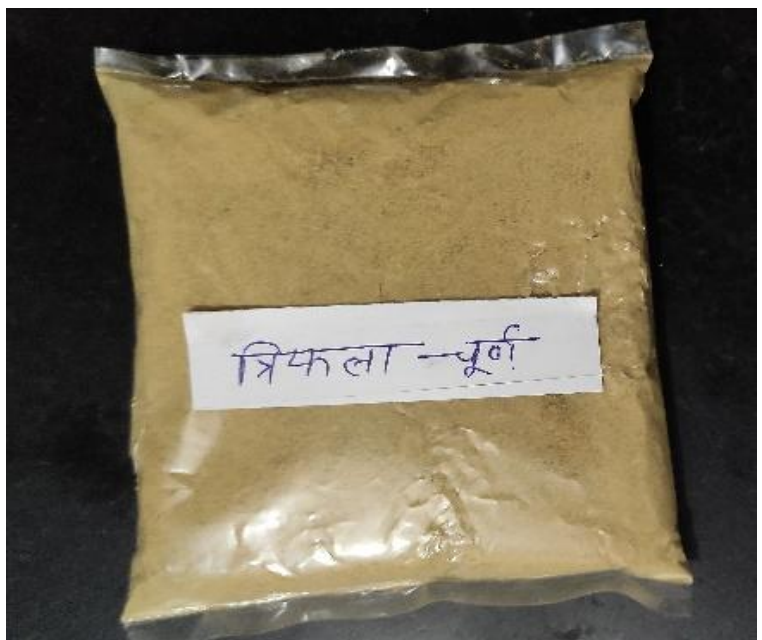

\section{RESULTS}

After a period of 30 days, the complains of swelling and bleeding from gums subside and calculus and debris were reduced substantially.

Oral Hygiene Index - Simplified (Green and Vermillion): After Treatment

\section{Debris Index:}

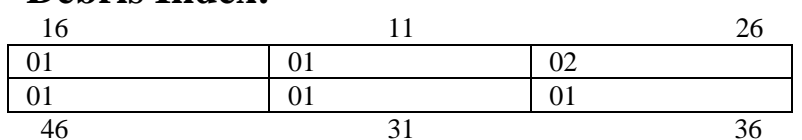

$\mathrm{DI}=7 / 6=1.16$ 
Calculus Index:

\begin{tabular}{|l|ll|ll|}
16 & 01 & & 02 & 26 \\
\hline 01 & 01 & & 01 & 36 \\
\hline 02 & \multicolumn{7}{|c|}{31} & & 36 \\
\hline 46 & & & & \\
\hline
\end{tabular}

$\mathrm{CI}=8 / 6=1.33$

$\mathrm{OHI}-\mathrm{S}=\mathrm{DI}+\mathrm{CI}=1.16+1.33=2.49$ (Fair

Oral Hygiene)
After treatment of one month, the oral hygiene index improved from poor to fair level. During follow up period of one month, there was no recurrence in the complain of patient and relief was achieved.

\section{BEFORE TREATMENT PICS:}

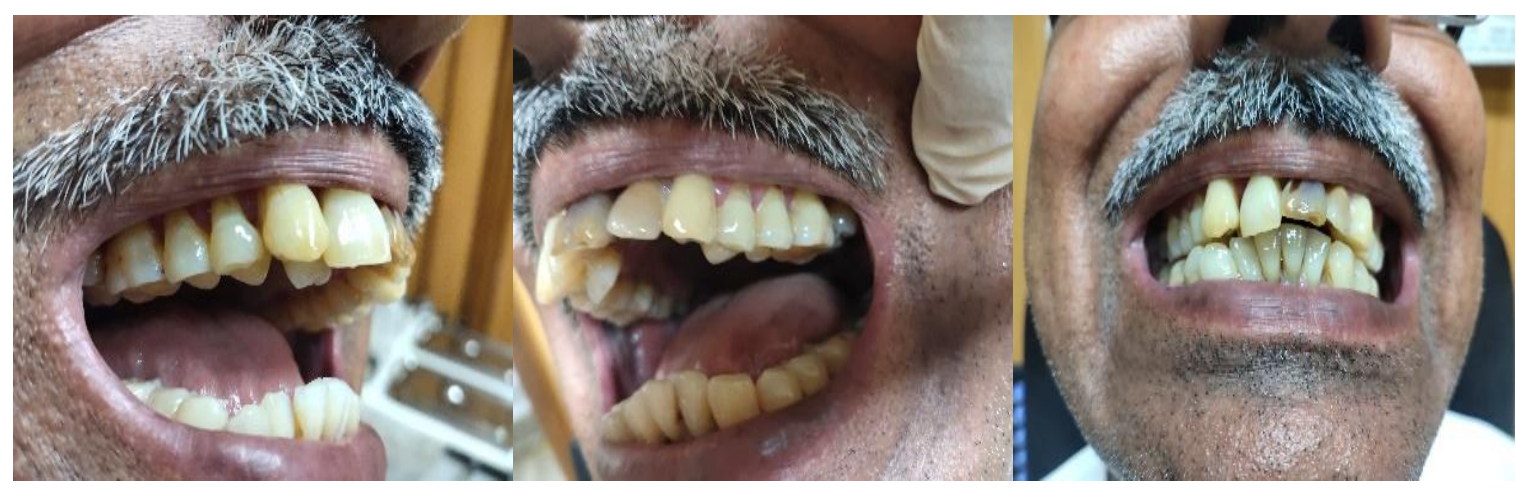

\section{AFTER TREATMENT PICS:}

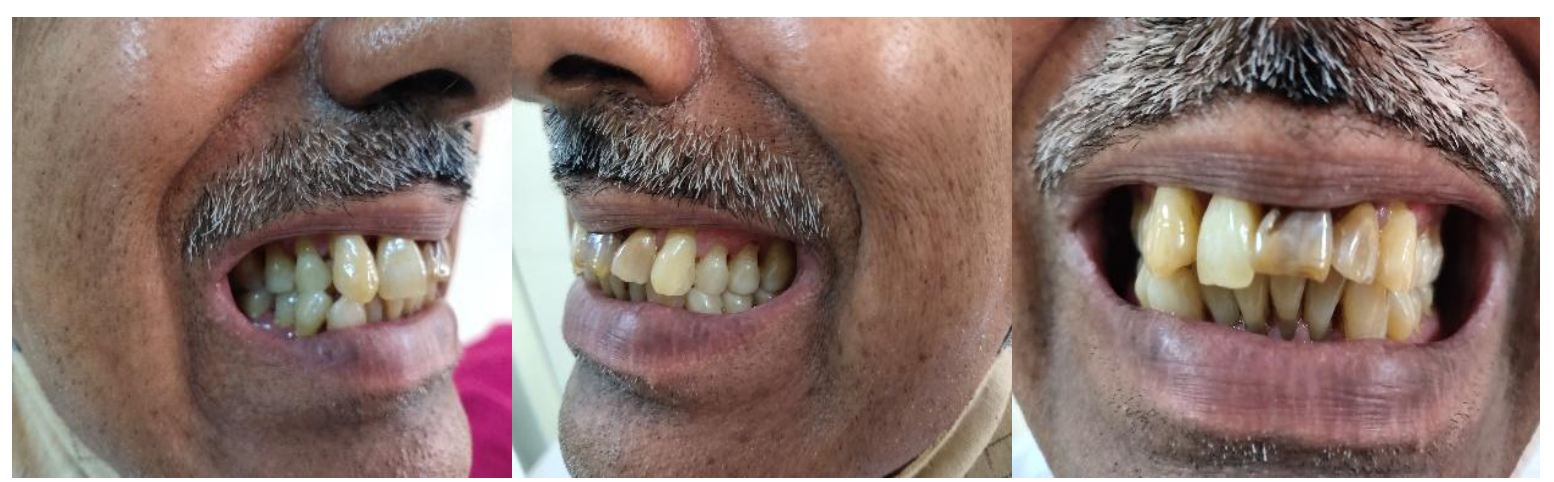

\section{DISCUSSION}

The etiology of poor hygiene in present case study is due to improper method of brushing of teeth which leads to accumulation of calculus and debris.

Gandusha is a type of Shodhana Chikitsa adopted in Mukha Pradesh. The oral cavity is the site of Bodhaka Kapha, as a result of which applied drug gets absorbed easily and faster and shows speedy recovery than systemic management.

It may also act by increasing the saliva which contains lysosomes and other detoxifying agent which again helpful in removal of infection and provide relief from symptoms.

The Kwath of drug used in lukewarm condition, which does locally
Kapha Shaman also leads to dosha Vilayana and clears Strotorodha. Prolonged and forceful mechanical action during Gandusha could play a vital part in dislodging calculus as well as debris from other part of mouth.

In Dantagorashani Churna, most of the drug are Katu Tikta Rasa, Laghu Ruksha Guna, Ushna Veerya and Katu Madhura Vipaka.

Katu Ras in Dantarogashani Churna cleanses the oral cavity due to property of Vaktra Shodhana and also destroys microorganisms i.e. Krimighna, reduces inflammation i.e. Shvyathukledamala Anauphatti, sticky slimy and waste discharge. 
Kaphaghna, Deepana and Pachana property helps in the radical removal of toxic substance from the oral cavity.

Due to properties of above mentioned drugs, the complain of swelling and bleeding from gums and halitosis subsided. Through the assessment of oral hygiene index we found that debris and calculus were reduced substantially.

\section{CONCLUSION}

Present case study showed that local application of Dantarogashani Churna and Triphala Churna Kwath Gandusha and oral hygiene measures are very effective in this case.

Despite the limitation of this case in a single patient, this treatment modality may be an eye opening for further studies to effectively manage oral hygiene through Ayurveda.

Acknowledgement: None

\section{Conflict of Interest: None}

\section{Source of Funding: None}

\section{REFERENCES}

1. Charak Samhita of Agnivesa elaborated by Charak and redacted by Drdhabala edited with 'Vaidyamanorama' Hindi Commentary, volumn 1 chapter 5, Published by Chaukhambha Sanskrit Pratishthan, Delhi, Reprint 2011, page no 81-105.
2. Sushruta Samhita with Ayurveda Tattva Sandipika Hindi Commentary By Kaviraj Ambikadutta Shastri, Part 2nd, Chapter 24th, Published by Chaukhambha Sanskrit Sansthan, Varanasi, reprint 2013, page no $131-143$

3. Astanga Hrdayam of Srimadvagbhata, edited with Nirmala hindi commentary by Dr.Brahmanand Tripathi, Chapter 2, Published by Chaukhambha Sanskrit Pratishthan, Reprint 2015, page no- 26-39

4. Kokoceva-Ivanovska OR, Sarakinova O, Zabokova-Bilbilova E, Mijoska AN, Stavreva N. Oral Hygiene Index in Early Childhood Caries, Before and After Topical Fluoride Treatment. Open Access Maced J Med Sci. 2018 Feb 1;6(2):378-383. doi: 10.3889/oamjms.2018.070. PMID: 29531609 ; PMCID: PMC5839453.

5. Bhaisajya Ratnavali of Kaviraj Govind Das Sen edited with Siddhiprada Hindi Commentary By Prof. Siddhi Nandan Mishra, Chapter 61, Mukhrogaadhikar, shloka no. 57 , published by chaukhamba surbharati prakashan Varanasi page no. 960

6. Sharangdhara Samhita, Dipika Hindi Commentary By Dr. Brahmanand Tripathi, Chaukhamba Surbharati Prakashan, Varanasi, edition 2016, Madhyam khand, churna Kalpana, shloka no - 9- 11, Page no -117 .

How to cite this article: Gawande S, Pamnani GC, Bhatnagar S. Management of oral hygiene through ayurveda: a case study. Int $J$ Health Sci Res. 2021; 11(10): 209-213. DOI: https://doi. org/10.52403/ijhsr.20211027 